\title{
Implementing a Student-Centered Pedagogy: Doing so in the Indonesian Teaching-Learning Context
}

\author{
Tabitha Julia Kidwell \\ Regional English Language Office (RELO) Center at AMINEF \\ 3rd Floor, CIMB Niaga Plaza \\ Jl. Jenderal Sudirman Kav. 25 Jakarta 12920 \\ tabithajulia@yahoo.com \\ Hanung Triyoko \\ RELO Counterpart \\ Jl. Tentara Pelajar No. 02 Salatiga, Central Java, Indonesia \\ hanungina@yahoo.co.id
}

\begin{abstract}
Today's educators must be willing to shift from the teacher-centered paradigm, which was in place when they themselves were students, to the new paradigm of student-centered education. This article was inspired by the challenges and opportunities experienced by the writers while attempting to implement a student-centered pedagogy. We will share some of our experiences as educators to provide a context for various aspects of student centered-learning. Understanding some of the successes and failures we have experienced in our careers may help to highlight the potential and importance of student-centered pedagogy in its many facets. Based on the vignettes from our teaching experiences, we have identified four major ideas about how to adopt a more studentcentered approach: planning lessons that encourage student interest; adapting the curriculum to meet student's needs; using technology in the classroom; and developing mutually respectful relationships.
\end{abstract}

Keywords: Student-Centered Pedagogy, Student's Interest, Student's Needs, Mutually Respectful Relationships 


\begin{abstract}
Abstrak
Pendidik saat ini harus rela berpindah dari paradigma yang berpusat pada guru, yang pernah mereka alami saat mereka masih mahasiswa, dengan paradigma baru pendidikan yang berpusat pada siswa. Artikel ini terinspirasi oleh tantangan dan peluang yang dialami para penulis ketika mencoba untuk menerapkan pedagogi yang berpusat pada siswa. Kami akan berbagi mengenai beberapa pengalaman kami sebagai pendidik dan menyediakan konteks yang sesuai untuk berbagai aspek pembelajaran yang berpusat pada siswa. Dengan memahami beberapa keberhasilan dan kegagalan yang kami alami dalam pengalaman mengajar kami bisa memungkinkan untuk menjabarkan potensi dan kepentingan pedagogi yang berpusat pada siswa dalam banyak sisi. Berdasarkan sketsa pengalaman mengajar kami, kami telah mengidentifikasi empat ide besar tentang bagaimana mengadopsi pendekatan yang lebih berpusat pada siswa: merencanakan pelajaran yang yang mendorong minat siswa, mengadaptasi kurikulum untuk memenuhi kebutuhan siswa, menggunakan teknologi di dalam kelas, dan mengembangkan hubungan yang saling menghormati.
\end{abstract}

Kata Kunci: Pedagogi yang Berpusat pada Siswa, Minat Siswa, Hubungan yang Saling Menghormati

\title{
Introduction
}

In education today, there are often discrepancies between what teachers plan and what students actually do in their learning process. This conflict is absolutely one of the things to consider when teachers want to improve the teaching-learning process in their classrooms. Today's educators must be willing to shift from the teacher-centered paradigm, which was in place when they themselves were students, to the new paradigm of student-centered education. This article was inspired by the challenges and opportunities experienced by the writers while attempting to implement a student-centered pedagogy. We hope to give a better picture of the necessary conditions for student-centered teaching and learning and to find local wisdom that enables all teaching staff at 
STAIN Salatiga, and at universities throughout Indonesia, to adopt this new paradigm of education.

We will share some of our experiences as educators to provide a context for various aspects of student centered-learning. Understanding some of the successes and failures we have experienced in our careers may help to highlight the potential and importance of student-centered pedagogy in its many facets. Our shared teaching careers include students on all 6 (inhabited) continents, with ages ranging from primary school students to adults, and we believe that the common themes evident in quite disparate situations speak to the universality of the power of student-centered pedagogy.

\section{Discussion}

\section{Interest}

\section{Vignette 1: Tabitha Kidwell}

I began my career in 2004 as a Peace Corps Volunteer English teacher in a secondary school in a small town in Madagascar. The school was quite underresourced; there were up to 70 students in one class, many of the classrooms did not have electricity, and there were no textbooks available. I had little teaching experience and limited knowledge of the local language and culture. As such, I relied heavily on the national curriculum and teacher-centered classroom activities. Some students were motivated and were able to excel, but far more were disenchanted with my class, the English language, and school in general. Classroom management, with so many students in one small room, was a major issue. I found I had the most successful time when I built lessons around aspects of the students daily lives. For example, the "food" 
lesson in the national curriculum included apples, bread, and beef as sample vocabulary items, but these did not correspond to the variety of foods that students ate on a daily basis.

I adapted the lesson to include rice, mangoes, beans. and other foods more familiar to students, and I brought in a shopping basket full of the actual items. I presented the vocabulary by removing one item from the basket at a time, slowly and suspensefully. Students were engaged in the presentation and enthusiastic about using their new vocabulary - many said they were going to teach their family over dinner that evening. By including content that was interesting to the students, as well as teaching methods that elicited their interest, I began to see the power that a student centered pedagogy could have.

\section{Research Review: Interest}

Researchers have identified three basic types of interest that contribute to learning: individual interest, situational interest, and, more recently, topic interest.

Individual interest reflects students' personal preferences, which are primarily influenced by their unique personalities. These interests develop over time and have long-lasting effects on a person's preferences, knowledge, and values. This type of interest can be focused on a specific school subject (e.g. science or literature) or specific activites within pop culture (e.g. music, sports, or movies) (Ainley, Hidi and Berndorff, 2002). Hidi's (1990) review of early research on the effects of individual interest showed that, when provided with material that individual students found interesting, students exhibited higher comprehension and recall, as well as more positive affect, and higher 
levels of perseverance and attention. This was generalizable across a variety of research studies involving various ages, levels, and subjects.

Situational interest is the inherant interestingness of a certain situation. This type of interest often is elicited by something in the environment, such as a text or conversation, and may have only a shortterm effect (Hidi, 1990). This type of interest plays an important role in learning when students do not have pre-existing interest in or knowledge about a certain academic area that is in the curriculum (Hidi and Harackiewicz, 2000). In a review of the research, Flowerday, Schraw, and Stevens (2004) identified several factors that lead to situational interest: text novelty, good organization, ease of comprehension, text coherance, vividness, and imagery.

As situational interest increases, engagement also increases, and attitudes become more positive (Flowerday, Schraw, and Stevens, 2004). Interesting stories and texts motivate people to read and positively influence their attitudes, comprehension, memory, depth of processing, and learning (Hidi, 1990). This is true for lectures, as well; lectures that are well constructed and include connections to student's expereinces were shown to be more effective at maintaining student interest levels (Tin, 2008).

If individual interest (which is generated by the student) and situational interest (which is generated by the environment) can be seen as a dichotomy, topic interest can be seen as the interestion of the two. Topic interest can be defined as the interest elicited by a word, title, or initial text that presents the reader with a topic. A study by Ainley, Hidi, and Berndorff (2002) confirmed that the development of topic interest comes from both individual interest (i.e., students who had previously 
identified a certain topic as an interest of theirs were more likely to be interested in topics connected to that domain) and situational interst (i.e. an interesting title might "grab" students" attention and get them started on the path to learning).

The same study also examined the processes inherent in developing topic interest and manifesting its effects. Interest in the topic of a text contributed significantly to positive student affect, which in turn encouraged persistance in working with the material, which then led to improved learning. Interestingly, Shirey and Reynolds (1988) found that adults actually tend to allocate less attention and fewer cognitive resources to information they find interesting, but remember it better, suggesting that they are efficient readers, and do not expend energy on information they will learn without extra effort.

All three types of interest can be expected to have positive effects on learning, and they are likely to interact and influence each other's development (Hidi, 1990). An individual's well-developed personal interests can evoke strong feelings of situational interest should a topic come up related to his or her individual interest. On the other hand, one specific experience of situational interest might lead an individual to take up a long-lasting individual interest in the topic. No matter the type of interest involved, "the key to maintaining interest lies in finding ways to empower students by helping them [find] meaning or personal relevance"( Hidi and Harackiewicz, 2000). One powerful way to do this is by presenting material in a more meaningful context that shows the importance of the learning or makes it personally relevant to students. 
The more that we can do as teachers to encourage and sustain student's interest, the more success our students will have. Identifying and using individual interests, such as giving music-related texts to students who enjoy playing guitar, can be highly effective. This can, however, prove quite time-consiming for teachers, especially if there is a high teacher-student ratio (Hidi, 1990). Additionally, not all students have unique and well-developed interests on which to draw (Hidi and Harackiewicz, 2000). Individual interests can best be incorporated on a large scale through student-choice. Students can be given a choice of reading topic, or the opportunity to give a presentation on a topic of interest to them. EFL class, where so much communication centers on the students' own beliefs and experiences, leads itself easily to this kind of adaptation. Rather than requiring all students to present or write about the same topic, like "The Importance of Education," teachers can allow for individual variation by selecting topics like "How Education has Affected my Life." Add to this the potential for students to communicate about their preferences, habits, families, aspirations, past experiences, and opinions, and you can see that EFL class offers many opportunities for the incorporation of individual interest.

An even more cost-effective strategy for teachers with large classes is to focus on developing situational and topic interest. If the class environment stimulates situational interest, students will be more motivated and are likely to make cognitive gains in areas where they initially had very little interest (Hidi and Harackiewicz, 2000). Focus on situational interest is more likely to lead to learning gains for all students. To do this, teachers must adapt materials or presentation modes to maximize situational interest. 
Regarding texts, if the provided text is very dry and uninteresting, situational interest will be an impossibility; replacing these texts with more interesting ones may be your only option. Familiarize yourself with English texts available in your school's library or language office, and keep an eye out for interesting stories online or in the Jakarta Post that could make for interesting alternate texts. Keep a file of these texts on hand to replace the truly unsalvagable texts. Often, however, texts can be adapted to encourage more situational interest. Teachers need not be afraid to modify texts if the outcome is better learning! Remember the elements that lead to situational interest: text novelty, good organization, ease of comprehension, text coherance, vividness, and imagery (Flowerday, Schraw, and Stevens, 2004). Structural modification, such as adding or deleting information, can increase good organization and text coherance. Additional details and imagery can be inserted to make texts more vivid. Some texts could also be modified to a context like "space aliens" (as in the research by Cordova \& Lepper, 1996, discussed above) simply by changing the names or places. To create text novelty, try to vary the texts used in class, and present them in different ways. Vividness and imagery can also be created by reading texts with students in class and having students act out or illustrate the stories they hear; you might even ask students to close their eyes and imagine the story as you read it aloud.

For class activities that do not involve texts, remember the power of novelty and suspense. Try to vary class activities so that students are not always stuck in the same routine; while some routine is helpful for classroom management, too much will make student's 'zone out.' One way to do this is to offer students meaningful choices, like choosing 
between writing an essay about the life of a historical figure, about an event in their own life, or about a recent television program they saw. All three options will practice the simple past tense, but the choice will satisfy students' needs for autonomy and will keep them more interested. Lastly, the simplest changes to your presentation style can do wonders to increase student learning. A student once told me about her favorite English teacher, but only detail that she could remember was that the teacher had a "magic bag" that she would pull items from when introducing vocabulary. What a basic but powerful way to make vocabulary presentations more engaging!

\section{Cultural contextualization and adaptation of the curriculum}

Vignette: H. Triyoko

When I was in junior and senior high school, every school in the province of Jawa Tengah used the same English textbook. At that time, teachers, not exclusively English teachers, were required to teach from books recommended by a higher authority, at the provincial level or even at the national level. These textbooks and the curriculum behind them had little significance to students' lives outside school, since the English textbooks were situated in a culture different from their own. It was not easy for me to understand names and events told in those books because those names and events were outside my own culture. Even though I was in many ways supported by teachers, friends, and other available resources of learning in the school, I often found learning English as inapplicable to my life. Had I not had a great intrinsic motivation to master English, I would have stopped learning English because of the many things I could not understand in my English textbooks. Many of 
my friends in junior and senior high schools only studied English to get a good grade; they saw English as compulsory subject that influenced their school achievement and no more than that. To compound the problem, teachers who were required to teach by the prescribed curriculum and textbooks were out of touch with the actual needs of the students.

When I became an English teacher myself, I realized that English was not a priority for many students. To remedy this, I attempted to expose students at STAIN, an Islamic university, to English for Islamic Studies as a branch of English for specific purposes. I hoped that there would be more opportunities for students to be aware that English is used not only to understand people from other cultures and religions, but that English can also be used to explain their own religion and cultures. For this course, I could not simply depend on a pre-determined curriculum or textbook because each class session came to follow the path of students' needs as they came up. There was no curriculum or textbook that could satisfy all the needs that occured during the classroom meeting. Creating resources to teach students was a burden for me, but it lead to increased student learning and insight. My students shared the understanding that English could be part of their life as a Muslim, and not solely a symbol of the western culture. Most of my students were really enthusiastic to talk in English about many concepts, values, and practices inherent in the study of Islam, since they generally learned and discussed those things in Arabic. Many of them were also challenged by the prospect of English as a means of sharing their Muslim faith. Secondly, my students could find more opportunities to contribute to the sharing of knowledge in the classrooms because we were discussing their own lives, experiences, and beliefs. I believe that many English teachers would improve their 
practice by providing more opportunities for students to personalize the learning materials and learning activities so that they can learn English in contexts familiar to their daily lives.

Literature Review: Cultural Contextualization and Adaptation of the Curriculum

In this paper, curriculum is defined as “...the content and purpose of an educational program together with their organization" (Walker, 1990). The governments of many nations have made efforts to have one common national curriculum. Supporters of the establishment of a national curriculum argue that a national curriculum serves as a symbol of nation's collective endeavours to improve education and protects the nation against individual choice led by the textbook market (Whitty, 1989). With the Indonesian government's limited education budget, many expenses are avoided by asking all provinces and districts to implement the same curriculum and to have national exams (Theisen, Hughes, and Spector, 1990). However, use of the national examination as a means to standardize the Indonesian education has been critisized by many educational practitioners in Indonesia as unfair and misleading. According to Wirdana (2008), one of the flaws in organizing national exams is its potential to devalue students as individual beings. The gap between regions in Indonesia, in term of education facilities, is wide; therefore, students' performances in the disadvantaged regions should not be measured with the same criteria used for students in the cities. Perhaps more importantly, the cultures of various students across the archipelago are ignored when all are taught using an identical curriculum that does not match their own background. 
Indonesia is missing out on a powerful phenomenon, for extensive research has showed that cultural contextualization and personalization has a significant effect on student learning. Ross (1983) conducted an interesting study of the effect of adapting the content of a presentation to student background. His context was math story problems, which were adapted to deal with education or health care for groups of pre-service teachers and nurses, respectively. Students who received content that was contextualized to match their background scored higher on post-tests. Therefore, assimilating new information to previous knowledge will be easier if the context is familiar, and therefore meaningful learning will be more likely. In a similar study, Cordova and Lepper (1996) showed that even simple embellishments to contextualize a topic (In their study, a math game designed to practice aritmetic operations was either contextualized in "outer space," "fantasy," or was not contextualized.) can lead to significant learning gains and higher motivation. Additionally, the personalization of the process (some students had the opportunity to personalize their computer programs, by adding their name and personal details) led to even greater learning gains, as well as, again, increased motivation and involvement.

Personalization can be applied at the cultural level as well students who read stories from their own culture have better understanding and recall than those reading stories from an unfamiliar cultural background; indeed, the cultural background has a greater effect than the syntactic or semantic difficulty of a text (Freimuth 2008). Cultural familiarity improves reading comprehension in many ways, such as "the speed of reading, reader perspective, recall of information, critical thinking, main idea construction processes as well as other reading 
processes" (Freimuth, 2008). This suggests that readings and classroom topics should be derived from the students' own culture and experience so that they can draw upon background knowledge.

Practical Suggestions: Cultural Contextualization and Adaptation of the Curriculum

Cultural contextualization is a balancing act. It is clear from contextualization research that when our texts and discussions are situated in a local context, they are more meaningful (Ross, 1983, Cordova and Lepper, 1996). On one hand, we want students to be successful on the national exams, and therefore we need to teach the national curriculum. On the other, we want students to be able to draw on their background knowledge (which is mostly situated in their local culture) to encorporate new knowledge to already existing schema. Schraw, Flowerday, and Lehman's (2001) suggestion is to "use texts that student's know about." At first, you will probably need to situate texts, lectures, and vocabulary presentations within the students' own culture. This is what brought me success in the English for Islamic Studies class, when I adapted my lessons to teach about topics of concern to students' own lives. As student's gain more language skills, you can move to teaching using texts and vocabulary that address the needs of the national curriculum. For more culturally-loaded texts, you will need to explicitly teach the aspects of culture that are unfamiliar by providing pre-reading background information.

In order to contextualize the curriculum, you must know the students' sociocultural background. For instance, if many students are from families of famers, an example sentences should be "Rudy's father 
plants rice." rather than "Rudy's father goes to the office." You should also keep an awareness that every class is unique - this helps teachers to be willing to review the curriculum at anytime they find it necessary. Though it may create more work for us to adjust the curriculum to anticipate students' needs, it is not a waste of time compared to the many hours spent teaching ineffective classes when we insist on applying identical curricula to all classes. In addition, the anticipation that every class is unique can give us the pleasure of expecting different learning situations, and can prevent our teaching jobs from becoming boring. In this way the curriculum serves students more in their learning processes in the classroom as students are put as the dominant factor in the design of curriculum.

What is the best resource in identifying student's sociocultural background, needs, and uniqueness? Of course, it is the students themselves! Teachers should negotiate with students how to change the classroom situation for the sake of learning. In order to encourage more students to openly express what they think of the learning situations in the classrooms, teachers can always provide time in the beginning of the class for students to reflect on their learning experiences in the previous classes and at the end of the class to collect ideas of what learning materials they want to bring to classrooms for the next meeting.

Through students' reflection, teachers learn how they think the teaching went. Especially when teachers encourage students to reflect on their learning experiences, teachers will be able to gain more insights on the needs of students and to change the situation of learning in the classroom by choosing classroom activities that best suit students preferences. Meanwhile, by openly discussing the learning objectives and 
by asking openly what learning materials students like to bring to class, teachers position themselves more as facilitators of learning than as the sole provider of knowledge. Though it may sound ridiculous for us teachers to involve students in preparing what to learn in classrooms, as many of us regard this process as exclusively the teacher's responsibility, it it will instill the feeling of responsibility to students for their own learning based on the materials they agreed upon. Furthermore, this can also be a good strategy to cope with the boredom students may feel when teachers use same old materials again and again, especially when they compare this to the plentiful interesting learning materials they can find on the internet. 


\section{Technology}

Vignette: H. Triyoko

It takes more than just learning in the classroom for students to see the significance of their lessons. If students seldom find opportunities to connect what they learn at school with their lives outside school, what is the purpose of learning? This was the situation when I learned English in school. I seldom found English used outside school except when I struggled to listen to English pop music broadcasted by local radio stations or English news broadcasted by a few international radio stations; of course, these were receptive media and did not provide any sort of interactive learning. The chances for me to meet English speaking people were also very limited as I lived in a village far away from the city and tourist locations.

Today, however, we face a very different situation. Thanks to the ubiquity of the internet, students can find many English learning materials and many opportunities to communicate in English. As a teacher, I know I can't compete with the internet, so I chose instead to benefit from it and therefore work smarter, not harder. I can always depend on the Internet to provide students with abundant materials and media, but I know that I need to be smart in my choice of the materials to be used in my English classrooms. Many times, I brought with me list of some very useful websites that students could browse themselves at home to help them improve their English mastery. Among my favorite sites were http://quizlet.com, http://www.vtrain.net, http://www.byki.com/fls/FLS.html, (for developing students' vocabulary), and http://www.radioaustralia.net.au/learnenglish, http://australianetwork.com/learningenglish, 
http://www.abc.net.au/transcripts, (for developing students' reading and listening skills). Rather than letting my students surf all the English learning websites that come up on internet search engines such as Google or yahoo, I spent considerable time discussing with my students the keywords to help them hit the most appropriate websites for their learning objectives, learning styles, and level of English mastery. By doing so, students are able to use much of their time to learn, rather than wasting it on browsing each of the websites listed.

\section{Literature Review: Technology}

Indonesian students learning English nowadays will find many opportunities to expose themselves to English as more programs on radios and shows on TV stations are delivered fully or dominantly in English. The chances become even greater when students access the internet, since students can select many multimedia materials (i.e. Music, videos, and texts) in English related to any topic that the student wants to learn about. Through the use of the Internet in students' learning, Warschauer (2003) asserts that learners will become autonomous and goal-directed, that classrooms will become centers of "collaborative and critical" inquiry, and that technology will have finally transformed schools to match the needs of the information society. Besides this, the internet also offers chances for students to get connected to English native speakers or other English learners around the world, creating an authentic communicative situation. Felix (1998) argues that the Web offers a wide variety of experiences beyond the confines of the curriculum. The Web brings the target culture and language not only into the classroom, but also potentially into the daily lives of students. The 
internet can also provide students with suitable materials related to their personal preferences and at the appropriate level of difficulty as long as students develop appropriate browsing skills. Wood (1999) says that "what is often missing from the huge array of Internet materials for pedagogic purposes is any clear identification of the new pedagogical opportunities that the Internet offers".

This is definitely the area where teachers can get involved in order to help students get the most benefit from using the internet, and if students share what they find, the teacher will benefit, too. Many teachers spend a lot of time selecting and incorporating materials from the internet, but it can be more efficient when teachers seek student contribution in the process. Teachers add rich materials to their own resources by accepting student contributions (Felix, 1998).

Regarding internet-facilitated learning, the roles of teacher may vary. At times they serve as facilitator and guide, or even as coresearcher and a co-learner, for instance when they work with the students to find the most suitable materials to meet student learning objectives, teach to many learning styles, and use in classroom activities. As the facilitator of learning, teachers need to ascertain that the materials agreed upon by students and teachers will be neither too difficult for students to understand, (therefore discouraging them from involvement in the learning process), or too easy (so that students are not challenged in the learning activities). With teachers' greater experience in learning English themselves, they can locate the materials exactly in their students' zone of proximal development, the challenge level proposed by Vigotsky as the most potential level for learning to occur. 
At other times, teachers need to be authoritative (but not authoritarian): They need to be a leader and a direct instructor who builds more systematic knowledge than the scattered materials accessed by students through the internet. In coping with the internet-facilitated learning, there are times when teachers are highly recommended to shift the pedagogic orientation from highly student-centered to a more guided investigation and direct instruction and vice versa (Unsworth, 2008)

The power of the internet to connect people from all parts of the world will not only change the way teachers teach, but also shape the whole structure of the English teaching and learning processes at schools as the internet also gives many influences in curriculum design, evaluation of student learning, and even the politics of education. Thanks to the many possibilities of the Internet to play a part in English teaching learning at schools, teachers are increasingly aware that traditional EFL classrooms remain a bounded context providing limited opportunities for communicative engagement (Thorne, Black, and Sykes, 2009). For instance, teachers cannot expect students to learn cross-cultural communication skills by having an English conversation with their classmates, as all of them are foreign to the target culture.

By using the Internet, however, students can make direct contact with native speakers and be involved in inter-cultural communication with various native speakers of English. In addition, the time for practicing English in classrooms is limited, whereas students have more flexibility in terms of time when communicating in English through the Internet. Teachers can also encourage students to join a community of learners that share the same interests with them. This will engage them 
in English communication in a borderless classroom, since the members of the learning communities may come from many regions of the world.

Internet usage can also, unfortunately, become a serious distraction. When students engage in activities on particular websites, such as reading pornographic texts or listening to speeches that provoke hatred and extremism, these activities have the potential to disconnect students from their learning objectives. To support students' educational goals for English learning, English teachers will need to be sensitive to existing priorities of use (Levy, M., 2009).

The more freedoms that students have in terms of choosing the English learning materials provided by the Internet shall not mislead students to attain to other unprecedented results as prescribed in the curriculum or as previously discussed by teachers and students in the initial stage of the course. When the focus of the course is to develop students' speaking abilities, for example, teachers need to ensure that students have the criteria to select good websites for developing their speaking skills. Teachers have to find ways to openly communicate with students the risks of the careless use of the internet so that students will develop their personal protections against those risks. Teachers will be challenged not merely to replicate what they are accustomed to doing in their classrooms, now with the aid of digital tools, but rather to maximize the benefits unleashed in this new learning environment (Black, R.J., 2009).

\section{Practical suggestion: Technology}

With all the ease of getting multimedia materials from the internet and with the existence of a new learning environment that absorbs more 
and more of students' time, many teachers are tempted to shift their traditional teaching practices drastically to new teaching practices. They hope to make the learning in classrooms as enjoyable as students' learning outside classrooms and to do so; they must involve information and communication technology. They often forget the irreplaceable roles of teachers in facilitating, managing, and controlling the learning in the classrooms - this gives us as significant an influence as the materials and the activities of learning.

Thus, English teachers who like to promote internet-facilitated learning as the new alternative to accelerate students' English learning process must first develop the awareness that they will and certainly can play an important role in students' learning; since the Internet will not do all the things they do as teachers. As mentioned earlier, the Internet provides many possibilities both to help and to distract students' learning because the use of the Internet is not an end in itself but it is just a means to an end. When students do no set particular goals for their engagement with the Internet, and when teachers fail to make these ends clear to students before an internet-based activity, students' use of the Internet will not give many advantages to their learning in particular. Indeed, the Internet will engage students in more activities which are not necessarily meaningful or helpful for their learning.

In order to play those irreplaceable roles in students' learning, particularly when in internet facilitated learning, the suggestions of Quinlan (2011) may be very useful: be well prepared before applying the internet-facilitated learning, be ready for surprises while applying the method, and be wise in selecting ways to measure students' learning outcomes. 
It is not wise to believe that all teachers applying the internet facilitated learning in their classrooms will turn out to be perfect teachers, since these kind of classrooms are not made in one night. Never expect that you will be able to successfully deliver lesson plans including the use of the Internet if you do not give your self sufficient time to get familiar with the kinds of materials provided by the internet and to judge if the materials are really useful and appropriate to achieve students learning objectives. Quinlan (2011) suggests that teachers shall not be trapped by the lure to show off what the Internet can do to make their classroom interesting and thus forget about students' learning objectives. Every website is designed for particular users and goals and thus not all websites have the potential to help students learn. Teachers need to evaluate whether the particular websites they intend to visit during their class really address students' needs and whether the activities are valuable. Teachers need to determine the possible usage of each website so that students will actually engage in purposeful learning process and not be distracted by the many other activities provided by the Internet.

While evaluating each website before using it in their classroom, put yourself in your students' shoes by anticipating various situations that students will face during their learning. Will all students be able to access the materials and be involved in the activities? Are they all familiar with the Internet, or will some of them become confused with what to do since they are not trained to use it? The degree of experience and expectations that the students have related to the use of the Internet can become a serious problem when teachers ignore it. Many students may resist the use of the Internet because they expect to be taught traditionally and they are not ready for the more autonomous learning experience. For some 
students it is strange to let the Internet control or guide their learning in the classrooms. Be ready for surprises while applying the Internet, and try to plan ahead for the situations that may occur due to the use of the Internet in your classroom. You also must be ready to apply a contingency plan when the Internet is not accessible due to poor connections or when the electricity is cut off.

Last but not least, while letting students experience the new learning facilitated by the Internet, evaluate the learning process using the same kinds of activities that students are engaged in online. If students are evaluated by measures that do hot relate to their work online, they will not see the value of the online work. For example, teachers can encourage students to spend time watching instructional cooking videos presented in English on Yои Tube if teachers then assess student performance through role plays where they themselves pretend to be chefs telling how to cook their favorite recipes in English. This is far superior to just assessing their cooking vocabulary mastery through quizzes or written examinations!

\section{Relationships}

Vignette: Tabitha Kidwell

My first salaried teaching position in the United States was teaching secondary students French and Spanish. My first year, like so many teachers' first years in the classroom, was a nightmare, mostly because of one class. As the most junior language teacher, I was asked to teach the class of students repeating their first year of Spanish. The first year of a language is fairly easy for most students, but these were all students with low academic abilities, behavior issues, and major family 
problems. They had already attempted Spanish and had failed, and therefore many of them not only were disinterested, but were actively opposed to learning the language, for fear of failing again. Teaching this class was a near-impossible feat, especially for a novice teacher. Very little learning took place. My attempts to coerce, cheerlead, or punish them into learning were all met with off-task behavior and disruptiveness. I stuck with it all year, though, and had the support of an excellent principal and colleagues. The school had adopted the educational philosophy of William Glasser, which holds that students (and all people) have five needs: survival; love and belonging; power or recognition; freedom; and fun. This framework helps explain many of the behaviors I saw that year.

For one, many of the students' needs for survival were not being taken care of at home, so they came to school already in a distressed frame of mind. On top of that, the most efficient way for them to achieve their other four needs was to torture their teacher. They self-identified as members of the "crazy" class (belonging), tried to hijack my lesson whenever possible (power), often refused to do work (freedom) and generally did whatever they felt like during class (fun). My principal helped me to see that, to teach these students successfully, you had to find a way to fulfill these needs in the classroom. The most effective teachers at that school were those who have a relationship of warmth and respect with students, and who used that relationship to ensure that all students' needs were met. In subsequent years, I also taught the "repeater" class, but did not find anything near to the difficulties of that first year. I credit this to the fact that I entered the classroom those years with the needs of the students at the forefront of my thinking. I thank 
those difficult students for teaching me just how important it is to know and value each student as an individual; the difficulties in that class my first year helped me to become a much more effective teacher in subsequent years.

\section{Research Review: Relationships}

While William Glasser's work, described above, certainly highlights the importance of quality teacher-student relationships, many other researchers have also emphasized this topic in recent years. Arum (2011) claims that recent educational reform efforts in the US, which had focused on relationships between adults or between adults and the curriculum, have failed because of their lack of focus on relationships between teachers and students.

Of course, the Indonesian teaching context is markedly different from that in America, and some readers may wonder if the idea of a realtionship is even appropriate for Indonesian society, where teachers have traditionally commanded a position of respect. Hargreaves (2001) acknowledges this, pointing out that "there is no ideal or optimal closeness of distance between teachers and others that transcends all cultures." Rather, there will be cross-cultural variations, and we must seek the appropriate balance for the Indonesian context.

Teachers may initially balk at the appropriateness of having a relationship with their students, but this is often due to the misunderstanding of the word 'relationship' as 'friendship.' It would indeed be inappropriate to put students at the level of peer or friend, or to spend the long hours outside of class that students tend to spend with friends, but there is still a relationship inherant in the teaching-learning 
context. Teachers can improve student learning by striving to make this realtionship meaningful; indeed, it would be foolish to leave this important relationship to chance (Marzano \& Marzano, 2003).

Frymier and Housier (2003) examined the communication skills important to teacher-student relationships. They found that many of the communication skills important to a good friendship are also essential to classroom relationships; this was particularily true for referential skill (explaining things clearly and facilitating understanding) and ego support (giving encouragement, making students feel like valued, empowered participants in the class). While referential skills represent those abilities that are traditionally associated with a good teacher, the importance of ego support skills suggest that there is more to being a good teacher than merely being qualified in the subject matter. When teachers endeavor to create a caring relationship with their students, they create a safe learning environment, where students are more likely to participate, ask questions when they do not understand, and achieve higher levels of learning.

Having conducted a meta-analysis of research related to effective classroom management, Marzano and Marzano (2003) found that a quality teacher-student relationship is the key to good classroom management; in fact, "teachers who had high-quality relationships with their students had 31 percent fewer discipline problems... over a year's time than did teachers who did not." Part of establishing this type of relationships builds upon teachers' traditional roles; they show an appropriate level of dominance, meaning that they establish clear expectations and consequences, communicate clear learning goals, and display assertive behavior. Successful teachers, therefore, make the terms of their relationships clear and comprehensible to students. In 
addition to this, however, successful teachers also establish appropriate levels of cooperation. They do this by providing flexible learning goals that sends the message that they care about student needs and interests. They take a personal interest in students' lives outside of school. They have positive classroom interactions with all students, letting each student know that their learning matters to the teacher.

\section{Practical Suggestions: Relationships}

Sometimes, teacher-student relationships develop organically, thanks to personalities of the teacher or the students. That, however, is not always the case, so teachers must consciously attempt to build relationships by adopting certain behaviours.

For one, get to know students as people. Learn each students' name and use it to greet them and call on them in class. Chat with students about their interests and lives before, during, and after class. If you hear about an important event in students' lives, like a drama production or athletic competition, make an effort to attend, or simply wish them luck and then follow up by asking how it went.

Secondly, teachers must show the students that they matter. Giles (2011) cites the example of a teacher who, before a lecture on child abuse, made a point of apoligizing if the lecture touched on any painful personal histories; this shows that the teacher cared about the student as a whole being rather than just as the recipient of academic knowledge. Think about how students might react to sensitive topics, and acknowledge this in class. If a student has been absent, ask them where they have been and if they have talked to classmates to get caught up. Students who are often absent usually are missing class for a good 
reason, such as a family or personal issue, and being aware of that situation can help you to teach that student more effectively.

Lastly, establish a climate of mutual respect. Strive to start class on time, avoid cancelling class, and fill classtime with meaningful activities; this shows students that their time matters to you. Allow and encourage all students to participate, and acknowledge student's participation. For example, you could say "Ratna just added to Fitri's idea by saying that..." (Marzano \& Marzano, 2003). Make eye contact with each student so that they know that you are aware of their presence and are expecting them to contirbute. Give each student an opportunity to feel successful in each class session, and be sure to call on students who do not commonly participate. Also, help students to avoid failure or embarrassment in front of their peers - nothing shuts down learning faster. 


\section{Conclusion}

Based on the vignettes from our teaching experiences mentioned above, we have identified four major ideas about how to adopt a more student-centered approach: planning lessons that encourage student interest; adapting the curriculum to meet student's needs; using technology in the classroom; and developing mutually respectful relationships. While we treated each topic under a separate heading, the reader may have noticed that the research and practical suggestions were quite similar throughout the article. In truth, establishing a studentcentered approach does not rely solely on the implementation of one new teaching method or style; it is a shift to focusing on student's needs and building the entire curriculum and educational situation around them. The many interrelated ideas presented in this article will each bring educators one step closer to meaningful student-centered pedagogy. Ultimately, though, the successful implementation of this new style of education will depend on each individual educator and their individual students. It will be an on-going process of negotiation and learning for each party, and its ultimate goal will be increased student learning. We wish you luck and success as you begin your journey towards this very worthy goal.

\section{References}

Ainley, M., Hidi, S., \& Berndorff, D. 2002. Interest, Learning, and the Psychological Processes That Mediate Their Relationship. Journal of Educational Psychology, 94, 545-561.

Arum, R. 2011. Improve Relationships to Inprove Student Performance. Kappan, October 2011, 8-13. 
Black, R.J. 2009. The Use of Technology for Second Language Distance Learning. The Modern Language Journal, 93, 822-835.

Cordova, D. I., \& Lepper, M. R. 1996. Intrinsic Motivation and the Process of Learning: Beneficial Effects of Contextualization, Personalization, and Choice. Journal of Education Psychology, 88, 715-730.

Felix, U. 1998. Language Learning on the Web: Finding the Gems amongst the Pebbles. ASCILITE98 Conference Proceedings. (215222)

Flowerday, T., Schraw, G., \& Stevens, J. 2004. The role of Choice and Interest in Reader Engagement. The Journal of Experimental Education, 72(2), 93-114.

Freimuth, H. 2008. The effect of cultural familiarity on the reading comprehension of L2 learners and what this means for URGU. URGU Journl, 6, 1-11.

Frymier, A. B., \& Houser, M. L. 2000. The Teacher-Student Relationship as an Interpersonal Relationship. Communication Education, 49(3), 207-219.

Giles, D. L. 2011. Relationships Always Matter: Findings from a Phenomenological Research Inquiry. Australian Journal of Teacher Education, 36(6), 80-91.

Glasser, William. 1986. Control theory in the classroom. New York, NY, US: Perennial Library/Harper \& Row Publishers.

Hargreaves, A. 2001. Emotional Geographies of Teaching. Teachers College Record 103(6), 1056-1080.

Hayati, A. M. 2009. The Impact of Cultural Knowledge on Listening Comprehension of EFL Learners. English Language Teaching, 2, 144-152.

Hidi, S. 1990. Interest and its Contribution as a Mental Resource for Learning. Review of Educational Research, 60, 549-571.

Hidi, S., \& Harackiewicz, J. M. 2000. Motivating the Academically Unmotivated: A Critical Issue for the $21^{\text {st }}$ Century. Review of Educational Research, 70, 151-179.

Levy, M. 2009. Technologies in Use for Second Language Learning. The Modern Language Journal, 93, 769-782

Marzano, R. J. \& Marzano, J. S. 2003. The Key to Classroom Management. Educational Leadership, 61(1), 6-13.

Quinlan, A.M. 2011. 12 Tips for the Online Teachers. Kappan Magazine.

December 2010/January 2011. 
Ross, S. M. 1983. Increasing the Meaningfulness of Quantitative Material by Adapting Context to Student Background. Journal of Educational Psycology, 75, 519-529.

Schraw, G., T. Flowerday, T., \& Lehman, S. (2001). Increasing Situational Interest in the Classroom. Educational Psychology Review, 13, 211-224.

Smith, D.L. and Lovat, T.J. 2003. Curriculum: Action on Reflection $\left(4^{\text {th }}\right.$ ed). Tuggerah, N.S.W.: Social Science Press

Shirey, L. L., \& Reynolds, R. E. 1988. Effects of Interest on Attention and Learning. Journal of Educational Psychology, 80, 159-166.

Theisen, G., Hughes, J., and Spector, P. 1990. An Analysis of the Status of Curriculum Reform and Textbook Production in Indonesia. Talahasee: Florida State University Press.

Thorne, S.L., Black, R.W., \& Sykes, J.M. 2004. Second Language Use, Socialization, and Learning in Internet Interest Communities and Online Gaming. The Modern Language Journal, 93, 802-821

Tin, T. B. 2008. Exploring the nature of the relation between interest and comprehension. Teaching in Higher Education, 13, 525-536.

Tomlison, B. and Dat, B. 2004. The contributions of Vietnamese learners of English to ELT methodology. Language Teaching Research, 8 (2) $199-222$

Unsworth, L. 2008. Multiliteracies, E-literature and English Teaching. Language and Education, 22 (1), 62-75

Walker, D. 1990. Fundamentals of Curriculum. Florida: Harcourt Brace Jovanovich, Inc.

Warschauer 2003. The Allures and Illusions of Modernity: Technology and Educational Reform in Egypt. Education Policy Analysis Archives, $11 \quad$ (38). $\quad$ Retrieved from http://epaa.asu.edu/epaa/v11n38/.

Wiseman, A.W., and Brown, D.S. 2003. Teacher Curricular Control and Student Performance: A Cross-National Study of Curricular Accountability. Curriculum and Teaching Dialogue 5 (2) 131-146

Whitty, G.. 1989. The New Right and the national curriculum: State control or market forces? Journal of Education Policy 4 (4) 329341

Wood, Robert. 1999. Thinking about the Internet pedagogically. Rutgers, The State University of New Jersey Campus at Camden. Retrieved 5 September 2011 10am from http://www.camden.rutgers.edu/\%7Ewood/pedagogy.html 
